\title{
Comparison of Nutritional Composition in Red and Green Strains of Kappaphycus Alvarezii Cultivated in Gorontalo Province, Indonesia
}

\author{
Ratih Ida Adharini* , Arief Rahmat Setyawan, Suadi, and Anes Dwi Jayanti, \\ Department of Fisheries, Faculty of Agriculture, Gadjah Mada University, Jl. Flora 1A Bulaksumur, \\ Yogyakarta, Indonesia.
}

\begin{abstract}
Kappaphycus alvarezii is the most widely grown seaweed known by the commercial name "cottoni." Several types or strains of $K$. alvarezii are grown in Indonesia, and each has a different appearance. There were red $K$. alvarezii, and green $K$. alvarezii collected from cultivation sites in Gorontalo Province, Sulawesi, Indonesia. The objective of this study was to compare the nutritional compositions of the red and green strain of $K$. alvarezii. The chemical composition analysis reveals that both strains contain ash, fat, crude fiber, protein, carbohydrate, vitamin $\mathrm{C}$, and minerals; $\mathrm{Ca}$ (Calcium), $\mathrm{Na}$ (Sodium), and Fe (iron). While the red strain shows a higher ash content $(4.62 \%)$, fat content $(0.05 \%)$, protein $(1.94 \%)$, carbohydrate $(5.24 \%)$, vitamin C (3.42 $\left.\mathrm{mg} .100 \mathrm{~g}^{-1}\right), \mathrm{Na}\left(467.65 \mathrm{mg} .100 \mathrm{~g}^{-1}\right)$, and $\mathrm{Fe}\left(30.10 \mathrm{mg} .100 \mathrm{~g}^{-1}\right)$, the green one has higher content of crude fiber $(0.64 \%)$ and $\mathrm{Na}\left(9,307.17 \mathrm{mg} .100 \mathrm{~g}^{-}\right.$ $\left.{ }^{1}\right)$. Based on the result, the red $K$. alvarezii contains higher ash, fat, protein, carbohydrate, vitamin $\mathrm{C}, \mathrm{Ca}$, and $\mathrm{Fe}$, while the green $K$. alvarezii is higher in water content, crude fiber, and $\mathrm{Na}$. These two strains have no significant differences in nutrient composition and mineral content.
\end{abstract}

\section{Introduction}

Kappaphycus alvarezii is the most popular seaweed-commercially known as "cottoni"and widely cultivated in Indonesia since it has relatively easy to cultivate, short production cycles, and low production costs [1]. K. alvarezii also cultivated in Gorontalo, Nunukan, East and West Nusa Tenggara, Kei Island, Bali, Java, Karimunjawa, and Lampung [2]. Although there are various strains of $K$. alvarezii, the most common ones are the dark red, brown, yellow, and greenish [3]. K. alvarezii has high economic value because it contains multipurpose, extractable kappa-carrageenan on its cell walls. The carrageenan is extensively used in the food industry (as a gelling, thickening, and stabilizing agent), pharmaceuticals, cosmetics, textiles, and organic fertilizers $[4,5,6]$.

In the field of pharmacology, carrageenan of $K$. alvarezii is the sources of dietary fiber and affecting hemagglutination activity. The carrageenan also has cholesterol-lowering, antioxidant, antibacterial, antimycobacterial, antiviral, anticancer, anti-inflammatory, and

${ }^{*}$ Corresponding author : ratih.adharini@ugm.ac.id 
anti-diabetic properties [7-11]. The growth rate and chemical composition of the seaweed are affected by several factors, namely, spatial and seasonal variation, reproductive status, geographical distribution, abiotic parameters, and species [1,12-17]. This study was aimed to compare the nutritional compositions of red and green $K$. alvarezii to provide some useful information for seaweed farmers, stakeholders, and industries.

\section{Methods}

\subsection{Sample Collection}

The red and green strains of Kappaphycus alvarezii were collected from seaweed cultivation sites in Popayato, Pohuwato Regency, Gorontalo Province, Sulawesi, Indonesia. The samples were stored in ice boxes for preservation. Then, in the laboratory, it was washed by distilled water and brushed using a soft brush to remove impurities and epiphytes. Afterward, it was dried and processed into powder using blender before subjected to nutrient and mineral content analyses.

\subsection{Water Content Analysis}

The moisture content was measured by heating [25]. The samples ( $2 \mathrm{~g})$ were dried in a universal oven (Memert, Germany) at a temperature of $100-105^{\circ} \mathrm{C}$ for $3-5$ hours until a constant weight was reached.

\subsection{Ash Content Analysis}

The ash content was determined by heating methods. The dry samples were burned to ashes for overnight in a muffle furnace (Shimidzu, Japan) at $800^{\circ} \mathrm{C}$ [25].

\subsection{Crude Protein Analysis}

The crude protein content was analyzed by the micro-Kjeldahl method, described in AOAC (2015). The sample $(0.5 \mathrm{~g})$ was weighed and put into a digestion tube, then added with $2 \mathrm{~g}$ of catalyst salt (a mixture of $\mathrm{Na}_{2} \mathrm{SO}_{4}$ and $\mathrm{HgO}$ ) and $2 \mathrm{~mL}$ of concentrated sulfuric acid $\left(\mathrm{H}_{2} \mathrm{SO}_{4}\right)$. Afterward, this solution was distilled and titrated with $\mathrm{HCl} \pm 0.02 \mathrm{~N}$.

\subsection{Fat Content Analysis}

The fat content was identified by the Soxhlet extraction method, as proposed [25], with petroleum ether as the solvent. It derived from the weight of the extracted fat in the bottom flask.

\subsection{Crude Fiber Content Analysis}

Following the standard reference method [25], the crude fiber content was determined by acid-base hydrolysis. It involved sequential acid-base pretreatment with $1.25 \% \mathrm{H}_{2} \mathrm{SO}_{4}$ and $1.25 \% \mathrm{NaOH}$ solution. After the extraction, the filter paper was dried in an oven (Memert, Germany) at $110^{\circ} \mathrm{C}$ for 2 hours. The crude fiber content was determined from the weight of the residue. 


\subsection{Carbohydrate Content Analysis}

The carbohydrate content was calculated using the following equation: $\%$ Carbohydrate $=$ $100 \%-(\%$ moisture $+\%$ ash $+\%$ crude fiber $+\%$ crude protein $+\%$ fat $)$.

\subsection{Biochemical Composition Analysis}

The vitamin $\mathrm{C}$ level was determined by titration using $0.01 \mathrm{~N}$ standard iodine, with $1 \mathrm{~mL}$ of $0.01 \mathrm{~N}$ iodine equal to $0.88 \mathrm{mg}$ of ascorbic acid. The gel strength was measured in a universal testing machine (Lloyd, UK), while the mineral profiles, including $\mathrm{Ca}$ (Calcium), $\mathrm{Na}$ (Sodium), and Fe (iron), were detected by AAS spectroscopy.

\subsection{Statistical Analysis}

The collected data were analyzed in SPSS v.18.0. The Kruskal-Wallis test was used to compare differences in the water content, ash, crude protein, carbohydrate, crude fiber, fat, vitamin $\mathrm{C}$, gel strength, and mineral profiles of the two strains of $K$. alvarezii with two replications. A significant difference is indicated by $\mathrm{p}<0.05$.

\section{Results}

\subsection{Proximate and biochemical composition}

Table 1. Nutrient composition of red strain and green strain K. alvarezii

\begin{tabular}{|c|c|c|}
\hline Nutrient composition & K. alvarezii (red strain) & K. alvarezii (green strain) \\
\hline Moisture content (\%) & $89.48 \pm 0.17$ & $90.66 \pm 0.15$ \\
\hline Ash (\%) & $4.62 \pm 0.04$ & $4.37 \pm 0.10$ \\
\hline Lipid (\%) & $0.05 \pm 0.00$ & $0.03 \pm 0.00$ \\
\hline Crude fiber (\%) & $0.40 \pm 0.05$ & $0.62 \pm 0.09$ \\
\hline Protein (\%) & $1.94 \pm 0.01$ & $1.79 \pm 0.01$ \\
\hline Carbohydrate (\%) & $5.24 \pm 0.12$ & $4.55 \pm 0.27$ \\
\hline Vitamin C (mg.100 g ${ }^{-1}$ ) & $3.42 \pm 0.03$ & $3.26 \pm 1.42$ \\
\hline
\end{tabular}

*Based on the Kruskal-Wallis test, all of the nutrient compositions in each species were not significantly different

$* *$ Values are expressed as mean \pm standard deviation, $\mathrm{n}=2$

The proximate composition of the red and green strains of $K$. alvarezii is presented in Table 1. The water content of green $K$. alvarezii $(90.66 \% \pm 0.15)$ was higher than red $K$. alvarezii $(89.48 \% \pm 0.17)$. The ash contents of both strains were not much different, i.e., $4.62 \% \pm 0.04$ was detected in red $K$. alvarezii and a lower proportion, $4.37 \% \pm 0.10$, was found in green $K$. alvarezii. The same case applied to fat content. Although the red strain had more fat content $(0.05 \% \pm 0.00)$ than the green one $(0.03 \% \pm 0.00)$, the difference was not significant. The crude fiber contained in both strains was somewhat low. The green strain had higher crude fiber $(0.62 \% \pm 0.09)$ than the red one $(0.40 \% \pm 0.05)$, but the difference was not statistically significant. The total contents of protein in the red and green strains were similar, i.e., $1.94 \% \pm 0.01$ and $1.79 \% \pm 0.00$, respectively. Carbohydrates are the second-highest component in $K$. alvarezii after water content. The red $K$. alvarezii had higher carbohydrate level $(5.24 \% \pm 0.12)$ than green $K$. alvarezii $(4.55 \% \pm 0.27)$. The former also had higher vitamin $\mathrm{C}\left(3.42 \mathrm{mg}, 100 \mathrm{~g}^{-1} \pm 0.03\right)$ compared to the latter $(3.26$ mg. $\left.100 \mathrm{~g}^{-1} \pm 1.42\right)$. 
Overall, the nutritional components of the two $K$. alvarezii strains in this research are lower than the analyzed red K. alvarezii of Abirami and Kowsalya in India [18] and green $K$. alvarezii of Ahmad et al. in Malaysia [19]. Such a difference implies that geographic and environmental factors play a role in the nutritional properties of seaweed. The growth rate and chemical composition of Kappaphycus are influenced by cultivation techniques, seasons, geographic features, and environmental conditions [6,20-22].

Based on the nutritional components of the two $K$. alvarezii strains, the red strain has higher levels of ash, fat, protein, carbohydrate, and vitamin $\mathrm{C}$ relative to the green one, which contains more water and crude fiber. In general, the nutrition compositions of both strains do not differ significantly. Similar to this present research, a study by HurtadoPonce [23] in the Philippines with the red, green, and brown K. alvarezii, claimed that there is no significant difference between the ash contents, as well as the proximate compositions, of these strains.

\subsection{Mineral Contents}

Table 2. Mineral contents of red strain and green strain K. alvarezii

\begin{tabular}{|c|c|c|}
\hline Mineral contents & K. alvarezii (red strain) & K. alvarezii (green strain) \\
\hline $\mathrm{Ca}(\mathrm{mg} .100 \mathrm{~g}-1)$ & 467.65 & 459.23 \\
\hline $\mathrm{Fe}(\mathrm{mg} .100 \mathrm{~g}-1)$ & 30.10 & 24.98 \\
\hline $\mathrm{Na}(\mathrm{mg} .100 \mathrm{~g}-1)$ & 6300.96 & 9397.17 \\
\hline
\end{tabular}

* Based on the Kruskal-Wallis test, all of the nutrient compositions in each species were not significantly different

The mineral profiles of the red and green strains of $K$. alvarezii are summarized in Table 2. The red strain had higher $\mathrm{Ca}$ and $\mathrm{Na}\left(467.65 \mathrm{mg} .100 \mathrm{~g} \mathrm{~g}^{-1} ; 30.10 \mathrm{mg} .100 \mathrm{~g}^{-1}\right)$ than the green strain (459.23 mg.100 g-1 $\left.24.98 \mathrm{mg} .100 \mathrm{~g}^{-1}\right)$. On the contrary, relative to red $K$. alvarezii (6300.96 mg.100 g-1), green K. alvarezii had higher levels of iron (Fe, 9397.17 mg. $\left.100 \mathrm{~g}^{-1}\right)$. Both strains of $K$. alvarezii have lower calcium levels but higher iron contents than the findings in Abirami and Kowsalya [18]. The variety of strains and regional geographic characteristics have been reported to cause different mineral profiles in one species [24]. Based on the Kruskal-Wallis test results, the difference between the mineral contents of the two strains was not statistically significant.

\section{Conclusion}

The comparison of red and green strains of $K$. alvarezii has proven that the former has a relatively higher level of ash, fat, protein, carbohydrate, vitamin $\mathrm{C}, \mathrm{Ca}$, and $\mathrm{Fe}$, while the latter contains higher water, crude fiber, and $\mathrm{Na}$. In general, there is no significant difference in their nutrient compositions and mineral contents.

\section{References}

[1] H. Indriani, Sumarsih, Budidaya, pengolahan, dan pemasaran rumput laut (Penebar Swadaya, Jakarta, 2003)

[2] R.I. Adharini, E.A. Suyono, Suadi, A.D. Jayanti, A.R. Setyawan. 2018, J. Appl. Phycol. 31, 725730 (2019)

[3] E.C. Schmidt, B.G. Nunes, M. Maraschin, Z.L. Bouzon, Photosynthetica 48, 161-172 (2010)

[4] K.S. Kumar, K. Ganesan, P.V.S. Rao, Food Chem. 107, 289-295 (2008).

[5] J. Necas, L. Bartosikova, Vet. Med. 58, 187-205 (2013) 
[6] A.Q. Hurtado-Ponce, I.C. Neish, A.T. Critchley, J. Appl. Phycol. 27, 1945-1961 (2015)

[7] L. Hayashi, R.P. Reis, Rev. Bras. Farmacogn. 22, 748-752 (2012)

[8] N. Nagarani, A.K. Kumaraguru, Front Life Sci. 6, 97-105 (2012)

[9] P. Rajasulochana, P. Krishnamoorthy, R. Dhamotharan, J. Chem. Pharm. Res. 4, 33-37 (2012)

[10] F.A. Diyana, A. Abdullah, Z.A.S. Hisham, K.M. Chan, Int. Food Res. J. 22, 1977-1984 (2015)

[11] A. Mayakrishnan, K. Sivakumari, P. Srinivasan, V. Kumari, Int. J. Drug Dev. Res. 5, 11(2017)

[12] R.I. Adharini, J. Kim, G. Kandasamy, H.G. Kim, Fish Aquat. Sci 19, 13 (2016)

[13] R.I. Adharini \& Kim. H.G., Ocean Science Journal 51, 477-483 (2016)

[14] E. Plougerne, K.L. Lann, S. Connan, G. Jechoux, F. Deslandes, V. Stiger-Pouvreau, Aquat. Bot.

85, 337-344 (2006)

[15] B.Y. May-Lin \& W. Ching-Lee, J. Appl. Phycol. 25, 805-815 (2013)

[16] P.N.M. Perfeto, Acta Bot. Bras. 12, 77-88 (1998)

[17] R.D. Otaiza, S.R. Abades, A.J. Brante, J. Appl. Phycol. 13, 161-171 (2001)

[18] R.G. Abirami, S. Kowsalya, J. Agr. Sci. Tech-Iran 5, 109-115 (2011)

[19] F. Ahmad, M.R. Sulaiman, W. Saimon, Y.C. Fook, P. Matanjun, Borneo Sci. 31, 85-96 (2012)

[20] R. Akmal. Syam, D.D. Trijuno, Rahmi, Darmawati, J. Appl. Biot. 2, 1-9 (2014)

[21] A.S. Kotiya, B. Gunalan, H.V. Parmar, M. Jaikumar, D. Tushar, J.B. Solanki, N.P. Makwana, Adv. Appl. Sci. Res. 2, 99-106 (2011)

[22] J. Flourence, Trends Food Sci. Tech. 10, 25-28 (1999)

[23] A.Q. Hurtado-Ponce, Botanica Marina 38, 215-219 (1995)

[24] A. Jensen, Hydrobiol 260-261, 15-23 (1993)

[25] AOAC guidelines (2015), 